\title{
Pengaruh Pengetahuan Akuntansi dan Jiwa Kewirausahaan Pada Penggunaan Informasi Akuntansi dalam Pembuatan Keputusan Investasi pada UMKM Kota Semarang
}

\author{
Sri Praptono, Rita Andini \\ Universitas Pandanaran, Indonesia \\ Email corresponding author: sri_praptono@yahoo.com/ritaandini007@gmail.com
}

\begin{abstract}
ABSTRAK
Penelitian ini memiliki dua tujuan. Pertama, untuk membuktikan pengaruh pengetahuan akuntansi pada penggunaan informasi akuntansi dalam pembuatan keputusan investasi. Kedua, pengaruh jiwa kewirausahaan pada penggunaan informasi akuntansi dalam pembuatan keputusan investasi. Data primer berupa jawaban kuesioner dari pelaku usaha UMKM Kota Semarangdengan menggunakan metode survey digunakan dalam penelitian ini. Adapun terdapat 98 sampel telah diperoleh dengan menggunakan metode sampling jenuh atau metode sensus. Metode analisis penelitian ini menggunakan analisis regresi linear berganda. Hasil pengujian hipotesis menunjukkan bahwa pengetahuan akuntansi berpengaruh positif pada penggunaan informasi akuntansi dalam pembuatan keputusan investasi. Jiwa kewirausahaan berpengaruh positif pada penggunaan informasi akuntansi dalam pembuatan keputusan investasi. Penelitian membuktikan pentingnya pengetahuan tentang akuntansi dan jiwa kewirausahaan bagi pengusaha dalam membuat keputusan investasi untuk masa depan usahanya.
\end{abstract}

Kata Kunci: pengetahuan akuntansi, jiwa kewirausahaan, penggunaan informasi akuntansi dalam pembuatan keputusan investasi

\section{PENDAHULUAN}

Banyak sekali cara untuk mewujudkan keinginan mempunyai kehidupan yang layak. Dimana salah satunya adalah menjadi wirausahawan. Keinginan untuk berwirausaha adalah hal yang sangat digemari oleh sebagian individu. Namun untuk berwirausaha tidaklah gampang, dimana dalam kegiatan wirausaha dibutuhkan bakat dan skill. Seorang wirausaha setidaknya harus mempunyai jiwa kewirausahaan dan pengetahuan akuntansi yang bagus demi kelangsungan bisnis yang dijalaninya. Seorang wirausaha sebaiknya memahami bagaimana pencatatan transaksi keuangan dan pelaporan akuntansi karena kegiatan bisnis itu tidak hanya melakukan kegiatan untuk jangka waktu satu bulan dan satu atau dua tahun saja tetapi bertahun - tahun, jadi tidak mungkin perusahaan akan mengingat semua transaksi yang terjadi dalam setiap kegiatan sebuah bisnis tanpa proses dan sistem pencatatan teratur dan sistematis, untuk itu dibutuhkan pengetahuan akuntansi untuk membuat suatu informasi akuntansi dalam sebuah bisnis yang dijalani (Krisanti, 2015).

Pencatatan transaksi keuangan juga sangat penting demi keuntungan yang ingin diraih ataupun kelangsungan usaha agar usaha tidak berhenti ditengah jalan. Banyak para wirausaha yang harus menutup usahanya hanya karena tidak ada pengetahuan akuntansi dalam membuat suatu keputusan akuntansi. Banyak yang tidak menghiraukan tentang pemisahan antara uang pribadi dan uang yang sudah masuk kedalam transaksi usaha, sehingga menyababkan tidak adanya laba atau keuntungan yang jelas dan modal usaha yang digunakan diawal. Itu bisa saja menyebabkan keuntungan yang bias. Dan jika terlalu lama keadaan itu dibiarkan, akan 
membuat usaha berhenti ditengah jalan. Dalam menjalankan sebuah bisnis atau usaha, tentu saja wirausahawan juga harus memikirkan kelangsungan usahanya. Pengambilan keputusan investasi menjadi salah satu tolak ukur untuk menjaga kelangsungan sebuah usaha. Namun dalam pengambilan keputusan investasi juga dibutuhkan pengetahuan akuntansi yang cukup untuk mampu membaca informasi akuntansi yang sudah dibuatnya dalam mengambil langkah investasi. Selain itu dalam pengambilan keputusan investasi juga harus dilihat sangat jeli oleh wirausahawan agar tidak merugikan usaha yang dijalaninya. Jiwa kewirausahaan juga berperan penting dalam pengambilan keputusan investasi. Besar kecilnya bentuk usaha juga mampu mempengaruhi seorang wirausaha untuk mengambil keputusan investasi yang diperlukan dalam usahanya. Pengaruh pendidikan kewirausahaan selama ini telah dipertimbangkan sebagai salah satu faktor penting untuk menumbuhkan dan mengembangkan hasrat, jiwa dan perilaku berwirausaha di kalangan generasi muda (Indarti dan Rostiani, 2008).

Terkait dengan pengaruh pendidikan kewirausahaan tersebut, diperlukan adanya pemahaman tentang bagaimana mengembangkan dan mendorong lahirnya wirausaha wirausaha muda yang potensial sementara mereka berada di bangku sekolah. Beberapa penelitian sebelumnya menyebutkan bahwa keinginan berwirausaha para mahasiswa merupakan sumber bagi lahirnya wirausaha - wirausaha masa depan ( Indarti dan Rostiani,2008). Berdasarkan penjelasan di atas, pengetahuan akuntansi dibutuhkan wirausahawan untuk menggunakan informasi akuntansi dalam memajukan usaha. Selain pengetahuan akuntansi, jiwa kewirausahaan juga merupakan faktor yang penting dalam memajukan usaha. Latar belakang dan beberapa penelitian diatas mendorong peneliti untuk melakukan penelitian tentang pengetahuan akuntansi, jiwa kewirausahaan, pemanfaatan informasi akuntansi dalam pengambilan keputusan investasi, dalam judul penelitian : Pengaruh Pengetahuan Akuntansi Dan Jiwa kewirausahaan Terhadap Penggunaan Informasi Akuntansi Dalam Pengambilan Keputusan Investasi. Adapun permasalahan yang dikaji dalam penelitian ini adalah (1) Apakah pengetahuan akuntansi berpengaruh terhadap penggunaan informasi akuntansi dalam pengambilan keputusan investasi? (2) Apakah jiwa kewirausahaan berpengaruh terhadap penggunaan informasi akuntansi dalam pengambilan keputusan investasi?

Salah satu hambatan pelaku usaha mikro kecil dan menengah (UMKM) di Kota Semarang dalam kesulitan mengakses permodalan pada lembaga kredit formal. Lantaran kini sudah banyak pembiayan UMKM tanpa agunan, namun salah satu faktor yang jadi kendala adalah banyaknya UMKM belum memiliki laporan keuangan usaha. Sedangkan pembukuan sangat berfungsi sebagai alat control pertumbuhan dan perkembangan usaha, pengendalian keuangan usaha, mengetahui kekayaan dan laporan laba, bahan penilaian kesehatan usaha, dan sebagai pertanggungjawaban pengelolaan usaha. Sebagian besar UMKM tidak memisahkan keuangan pribadi dengan keuangan usaha, padahal kemampuan mengelola keuangan pribadi atau keluarga sangat berpengaruh terhadap pengelolaan keuangan usaha. UMKM masih mengandalkan ingatan untuk menghitungbeberapa banyak uang yang dibelanjakan atau hasil perolehan penjualannya.

Penelitian yang dilakukan oleh Sari dan Dwirandra (2015) yang berjudul Pengaruh kepribadian wirausaha dan pengetahuan akuntansi pada penggunaan informasi akuntansi dalam pembuatan keputusan investasi. Hasil Penelitian menunjukkan bahwa variabel kepribadian wirausaha dan variabel pengetahuan akuntansi secara signifikan berpengaruh positif terhadap penggunaan informasi akuntansi. Penelitian yang ketiga dilakukan oleh Listiorini dan Ika (2018). Pengaruh jenjang pendidikan dan pelatihan akuntansi terhadap penggunaan informasi akuntansi pada usaha UMKM. Adapun hasil dari penelitian ini menunjukan bahwa secara simultan, keseluruhan variabel penelitian ini yaitu jenjang pendidikan pemilik dan pelatihan akuntansi berpengaruh terhadap penggunaan informasi akuntansi pada usaha mikro, kecil dan 
menengah. Sedangkan secara persial, jenjang pendidikan tidak berpengaruh signifikan terhadap penggunaan informasi akuntansi pada Usaha Mikro Kecil dan Menengah. Sementara itu untuk variabel pelatihan akuntansi berpengaruh signifikan terhadap penggunaan informasi akuntansi pada Usaha Mikro Kecil dan Menengah.

Pemahamam tentang akuntansi sangat diperlukan bagi wirausahawan dalam menggunakan informasi akuntansi dalam pembuatan keputusan investasi. Wirausahawan juga dituntut untuk memiliki jiwa kewirausahaan yang baik. Jiwa kewirausahaan merupakan suatu kepribadian yang kreatif, mampu membaca peluang, membuat suatu produk unik, mampu membantu kehidupan masyarakat lainnya serta dapat menghasilkan suatu kelebihan untuk pengembangan usahanya. Jiwa kewirausahaan juga berperan penting dalam pengambilan keputusan investasi. Besar kecilnya bentuk usaha juga mampu mempengaruhi seorang wirausaha untuk mengambil keputusan investasi yang diperlukan dalam usahanya (Sugiarto, 2010). Hasil penelitian Krisanti (2012) membuktikan jiwa kewirausahaan yang tinggi yang dimiliki oleh wirausahawan mempengaruhi penggunaan informasi akuntansi dalam membuat keputusan yang berkaitan dengan investasi. Perilaku wirausahawan dalam prosesnya akan dipengaruhi oleh usia. Usia mempengaruhi wirausahawan dalam melakukan investasi. Di saat usia yang tergolong masih muda seseorang cenderung lebih semangat dan lebih berani menghadapi resiko dalam melaksanakan aktivitasnya. Hal ini disebabkan oleh kondisi fisik yang kuat, serta rasa keingintahuan yang tinggi (Hisrich,1995) dalam Tayras (2010).

Sinha (1996) dalam penelitiannya yang dilakukan di India membuktikan bahwa kebanyakan wirausahawan yang memperoleh kesuksesan adalah wirausahawan yang memiliki usia masih muda. Menurut Indarti dan Rostiani (2008) menyatakan bahwa variabel usia tidak berpengaruh terhadap intensi kewirausahaan. Terdapat ketidakkonsistenan hasil dari penelitianpenelitian sebelumnya, sehingga dalam penelitian ini, dilakukan kembali penelitian dengan tujuan untuk menguji persepsi pengusaha UMKM terhadap faktor-faktor yang mempengaruhi penggunaan informasi akuntansi didalam membuat keputusan yang berkaitan dengan investasi. Penelitian ini berfokus pada faktor internal pelaku usaha (faktor dari dalam diri sendiri). Sesuai dengan Theory of Planned Behavior (TPB), kontrol perilaku persepsian (perceived behavioral control) dipahami sebagai pengetahuan akuntansi dan sikap terhadap perilaku (attitude towards behavioral) dipahami sebagai jiwa kewirausahaan mempengaruhi prilaku wirausahawan dalam menggunakan informasi akuntansi dalam pembuatan keputusan investasi. Dengan TPB bisa dilihat sejauh mana persepsi pengusaha UMKM terhadap pengetahuan akuntansi dan jiwa kewirausahaan akan mempengaruhi keputusan investasinya. Dalam penelitian ini juga memasukkan usia sebagai variabel kontrol untuk membatasi atau sebagai pengendali terhadap variabel-variabel lainnya. Dalam penelitian ini menggunakan responden pengusaha UMKM di Kota Semarang.

Informasi ini akan menjadi acuan dalam proses pemberian kredit, dimana semakin tinggi pengetahuan akuntansi yang dimiliki oleh pelaku usaha maka pelaku usaha tersebut akan dapat memberikan laporan yang akurat dan relevan tentang kinerja dan keuangan perusahaanya, sedangkan semakin tinggi jiwa kewirausahaan yang dimiliki maka akan dapat menjamin kelangsungan usahanya sehingga mampu untuk memenuhi kewajibannya kepada pelaku UMKM. Penelitian ini mempunyai kontribusi teori terhadap akademisi secara umum yaitu menerapkan TPB untuk fenomena ini dapat menjadi acuan implementasi bagi praktisi terutamanya praktisi kewirausahaan dan pelaku bisnis dalam pembuatan keputusan investasi. Penelitian ini juga bermanfaat bagi lembaga keuangan khususnya UMKM dalam menjaring dan menyalurkan pembiayaan.

Adanya ketidakkonsistenan hasil dari penelitianpenelitian sebelumnya menjadi motivasi penelitian ini, terutama untuk membuktikan bahwa pengetahuan akuntansi pelaku UMK akan menguatkan peranan jiwa kewirausahaan yang dimiliki ketika membuat keputusan investasi. 
Mengacu pada konstruk Theory of Planned Behavior (TPB), pengetahuan akuntansi dapat dipahami sebagai norma subyektif dan sikap terhadap perilaku, sedangkan jiwa kewirausahaan dipahami sebagai persepsi diri untuk mengontrol perilaku yang dibatasi oleh kekurangan dan keterbatasan sumber daya yang digunakanya. Dengan demikian, melalui TPB, perilaku seseorang dalam membuat keputusan dipengaruhi oleh persepsinya, sehingga dapat dikatakan bahwa persepsi tentang pengetahuan akuntansi dan jiwa kewirausahaan pelaku UMK akan mempengaruhi keputusan investasinya.

\section{METODE PENELITIAN}

Penelitian ini mengambil lokasi Kota Semarang, khususnya para pengusaha UMKM. Data yang digunakan adalah data primer yang diperoleh langsung dari sumber asli (tidak melalui media perantara) yang secara khusus dikumpulkan oleh peneliti untuk menjawab penelitian (Ruslan, 2003). Data primer dalam penelitian ini adalah jawaban responden atas pernyataan atau pertanyaan dalam kuesioner penelitian yang dikumpulkan dengan menggunakan metode survei.

Teknik penentuan sampel yang digunakan dalam penelitian ini adalah sampling jenuh atau metode sensus. Metode ini digunakan bila semua anggota populasi digunakan sebagai sampel (Sugiyono, 2014), maka jumlah sampel yang digunakan dalam penelitian ini adalah sebanyak 98 orang responden yang merupakan pelaku UMKM di Kota Semarang. Penelitian ini bertujuan untuk melihat persepsi pengusaha UMKM terhadap pengaruh penggunaan informasi akuntansi dalam hubungan antara jiwa kewirausahaan dan pembuatan keputusan investasi.

Persepsi pengusaha UMKM terhadap jiwa kewirausahaan diukur dengan beberapa pertanyaan menggunakan skala likert dengan pemberian skor 1 untuk pilihan Sangat Tidak Setuju (STS), skor 2 untuk pilihan Tidak Setuju (TS), skor 3 untuk pilihan Netral (N), skor 4 untuk pilihan Setuju (S), dan skor 5 untuk pilihan Sangat Setuju (SS).

Hal ini dapat diukur dari pernyataan kuesioner yang akan digunakan oleh peneliti. Kuesioner yang digunakan dalam penelitian ini. Pertanyaan kuesioner terkait dengan jiwa kewirausahaan (entrepreneurial mindset) yaitu Actions oriented, berpikir simple, fokus pada eksekusi, dan mengejar peluang dengan disiplin tinggi. Pengukuran persepsi pengusaha UMKM terhadap penggunaan informasi akuntansi dalam pembuatan keputusan investasi menggunakan skala likert dengan pemberian skor 1 untuk pilihan Sangat Tidak Setuju (STS), skor 2 untuk pilihan Tidak Setuju (TS), skor 3 untuk pilihan Netral (N), skor 4 untuk pilihan Setuju (S), dan skor 5 untuk pilihan Sangat Setuju (SS).

Hal ini dapat diukur dari pernyataan kuesioner yang akan digunakan oleh peneliti. Pertanyaan kuesioner terkait dengan kemampuan membaca laporan keuangan sebagai informasi, pemahaman laporan keuangan untuk pembuatan keputusan investasi, dan analisa laporan keuangan untuk penilaian investasi. Pengetahuan akuntansi merupakan seperangkat ilmu yang tersusun secara sistematis tentang proses mencatat, mengklasifikasi, meringkas, mengolah dan menyajikan data transaksi serta kejadian yang berhubungan dengan keuangan yang dapat digunakan dan mudah dimengerti oleh pihak yang berkepentingan dalam pengambilan suatu keputusan. Persepsi pengusaha UMKM terhadap pengetahuan akuntansi diukur dengan beberapa pertanyaan menggunakan skala likert dengan pemberian skor 1 untuk pilihan Sangat Tidak Setuju (STS), skor 2 untuk pilihan Tidak Setuju (TS), skor 3 untuk pilihan Netral (N), skor 4 untuk pilihan Setuju (S), dan skor 5 untuk pilihan Sangat Setuju (SS).

Persepsi pengusaha UMKM terhadap pengetahuan akuntansi diukur dengan Pertanyaan kuesioner terkait dengan pemahaman responden terhadap bentuk-bentuk laporan keuangan, penggunaan laporan keuangan, dan laporan keuangan sebagai suatu informasi akuntansi untuk 
pembuatan keputusan investasi. Metode pengumpulan data yang digunakan dalam penelitian ini adalah dengan metoda wawancara terstruktur menggunakan kuesioner. Kesungguhan responden dalam menjawab kuesioner merupakan hal yang sangat penting, karena keabsahan (validitas) suatu hasil penelitian sangat ditentukan oleh alat ukur instrumen yang digunakan dan data yang diperoleh. Berdasarkan pertimbangan tersebut, selanjutnya dilakukan pengujian instrumen untuk menunjukkan jawaban responden telah dijawab dengan benar atau tidak. Pengujian tersebut meliputi uji Reliabilitas (keandalan) dan uji Validitas. Pengujian Asumsi Klasik dibutuhkan sebagai syarat analisis kausalitas yang menggunakan Regresi agar terbebas dari bias yang mengganggu model kausalitas. Pengujian meliputi Uji Normalitas, danUji Heteroskedastisitas.

Analisis Regresi Moderasi (MRA) Analisis regresi moderasian adalah studi mengenai ketergantungan variabel dependen (terikat) dengan satu atau lebih variabel independen (variabel penjelas/bebas), dikuatkan atau dilemahkan oleh variabel lain yang turut menjelaskan variabel terikat. Adapun tujuannya adalah untuk mengestimasi dan/atau memproduksi rata-rata populasi atau nilai-nilai variabel dependen berdasarkan nilai variabel independen bersama dengan variabel moderasian yang diketahui (Ghozali, 2013). Pengujian menggunakan pengujian Koefisien determinasi (R2), Uji Kelayakan Model (Uji F), dan

Uji Hipotesis (Uji t). Persamaan Regresi dalam penelitian ini adalah:

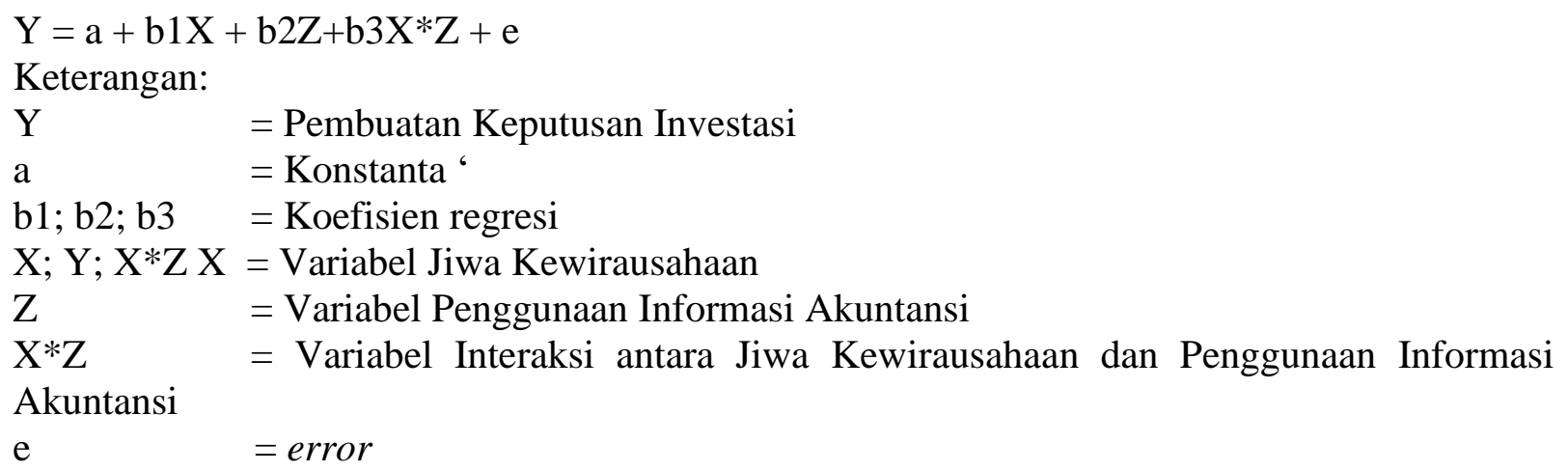

\section{HASIL DAN PEMBAHASAN}

Data pada penelitian diperoleh dengan menyebarkan kuesioner kepada 98 responden. Pendistribusian kuesioner dilakukan dengan cara mendatangi secara langsung dan melakukan pendampingan kepada pelaku UMKM yang merupakan sampel dalam penelitian ini. Semua kuesioner terisi sehingga jumlah sampel yang diolah adalah sebanyak 98 sampel. Profil responden yang memaparkan mengenai jenis kelamin, usia, pendidikan terakhir, dan jenis usaha dari pengusaha UMKM didominasi pada kisaran usia 25-50 tahun yaitu sebanyak 82 orang $(83,67 \%)$. Hal ini menunjukkan bahwa tingkat kematangan usia berpotensi untuk menjelaskan perilakunya. Pada usia 25-50 tahun seseorang lebih bersemangat dalam berwirausaha karena pada usia tersebut merupakan tahap kemapanan dengan kebutuhan hidup yang tinggi. Jika didasarkan dari jenis kelamin, pengusaha UMKM laki-laki lebih banyak dibandingkan dengan perempuan yaitu sebanyak 64 orang $(65,31 \%)$. Disisi lain, tingkat pendidikan dapat menunjukkan niatan seseorang untuk berwirausaha. Berdasarkan tabel di bawah dapat dilihat bahwa orang yang berwirausaha didominasi oleh para wirausaha yang lulusan SMA yaitu sebanyak 51,02 \%. Ditinjau dari jenis usahanya, jenis usaha perdagangan yang paling banyak ditekuni oleh pengusaha UMKM yaitu sebanyak 49 orang (50\%). Berdasarkan profil responden, menunjukkan sampel penelitian ini cukup representatif karena 
anggota sampel memiliki karakteristik demografi beragam, baik dari jenis kelamin, usia, pendidikan terakhir serta jenis usaha yang ditekuni.

Berdasarkan hasil pengujian ditemukan bahwa interaksi pengetahuan akuntansi dengan jiwa kewirausahaan berpengaruh positif pada pembuatan keputusan investasi. Hal ini menunjukkan bahwa pengetahuan akuntansi sangat diperlukan oleh pelaku usaha UMKM guna menunjang jiwa kewirausaan yang dimiliki ketika membuat keputusan investasi. Pengetahuan akuntansi digunakan untuk memahami informasi akuntansi dalam pembuatan keputusan investasi. Semakin tinggi pengetahuan akuntansi seorang wirausaha maka semakin besar pemanfaatan informasi akuntansi yang digunakan dalam pembuatan keputusan investasi. Sebaliknya semakin rendah pemahaman seseorang terhadap pengetahuan akuntansi maka semakin sedikit pemanfaatan informasi akuntansi dalam rangka pembuatan keputusan investasi.

Hasil penelitian ini sejalan dengan temuan Suhairi (2004), Krisanti (2012), Aprianto (2014), Linawati (2015) serta Sari (2015). Penelitianpenelitian tersebut membuktikan bahwa jika seorang wirausaha memiliki pengetahuan tentang akuntansi yang baik maka wirausaha ini akan dapat menggunakan dan memahami informasi-informasi akuntansi yang digunakan dalam pembuatan keputusan investasi. Begitu pula sebaliknya jika seorang wirausaha tidak memiliki pengetahuan akuntansi yang baik maka wirausaha ini tidak akan dapat memahami dan menggunakan informasi akuntansi dengan baik. Selanjutnya, hasil penelitian ini berbeda dengan penelitian yang dilakukan oleh Roundah (2008) dan Pradnyadewi (2015) yang membuktikan bahwa pengetahuan akuntansi tidak berpengaruh terhadap penggunaan informasi akuntansi dalam pembuatan keputusan investasi. Hasil penelitian ini juga memberikan dukungan empiris terhadap TPB, dimana TPB mengontrol perilaku individual yang dibatasi oleh kekurangankekurangan dan keterbatasan dari sumber daya yang digunakan untuk melakukan perilakunya. Pengetahuan akuntansi dipahami sebagai perceived behavioral control yang mempengaruhi perilaku individu dalam pembuatan keputusan. Perceived behavioral control merupakan persepsi kemudahan dan kesulitan dalam melakukan suatu perilaku berkaitan dengan keyakinan tentang ketersediaan dukungan dan sumber daya atau hambatan untuk berperilaku. Perilaku dalam pembuatan keputusan dalam hal ini adalah penggunaan informasi akuntansi. Informasi akuntansi akan sangat mudah dipahami apabila didukung oleh kemampuan pengetahuan akuntansi yang dimiliki oleh pengusaha UMKM. Hasil penelitian ini sejalan dengan temuan Hadayati (2014) dan Lee (2008) yang menyatakan bahwa perceived behavioral controldapat memberikan pemahaman terhadap seseorang mengenai mudah atau tidaknya suatu informasi yang diberikan. Hasil pengujian hipotesis menunjukkan bahwa jiwa kewirausahaan berpengaruh positif padapenggunaan informasi akuntansi dalam pembuatan keputusan investasi. Penelitian ini membuktikan bahwa semakin tinggi jiwa kewirausahaan seseorang maka semakin tinggi keingintahuannya tentang informasi akuntansi dan akan menggunakan informasi akuntansi dalam pembuatan keputusan investasi usahanya. Wirausahawan yang memiliki jiwa kewirausahaan yang tinggi cenderung akan selalu berusaha mengembangkan usahanya termasuk dalam penggunaan informasi akuntansi dalam pembuatan keputusan investasi.

Hasil ini sejalan dengan temuan Sugiarto (2010), Krisanti (2012) dan Sari (2015) yang menyatakan bahwa nilai kepribadian wirausaha yang tinggi seperti lokus pengawasan internal dan keinginan berprestasi yang tinggi cenderung memilih Made Gede Wirakusuma, Pengaruh Penggunaan Informasi cara bersaing yang berbeda, termasuk dalam penggunaan informasi akuntansi. Hasil penelitian ini juga memberikan dukungan empiris terhadap kontruk TPB yaitu sikap terhadap perilaku. Sikap terhadap perilaku merupakan suatu faktor dalam diri seseorang yang dipelajari untuk memberikan respon positif atau negatif pada penilaian terhadap sesuatu yang diberikan. Apabila seseorang menganggap sesuatu hal bermanfaat bagi dirinya maka dia 
akan memberikan respon positif terhadap hal tersebut, sebaliknya jika sesuatu tersebut tidak bermanfaat maka orang tersebut akan memberikan respon negatif. Dalam penelitian ini jiwa kewirausahaan dipahami sebagai sikap terhadap perilaku yang mempengaruhi minat perilaku individu dalam pengambilan keputusan. Semakin tinggi jiwa kewirausahaan seseorang (respon positif) maka akan semakin memicu seseorang untuk mencari segala informasi untuk memajukan usahanya termasuk informasi akuntansi yang digunakan untuk pembuatan keputusan investasinya. Hasil penelitian ini sejalan dengan temuan Panggalih (2013) serta Nazar dan Syahran (2008). Penelitian tersebut menemukan bahwa munculnya minat perilaku seseorang dipengaruhi oleh munculnya sikap awal dari seseorang terhadap minat perilaku tersebut. yaitu

Berdasarkan pembahasan yang telah diuraikan, terdapat keterbatasan dalam penelitian ini

(1) Penelitian ini hanya menggunakan dua dari tiga kontruk TPB yaitu perceived behavioral control dan sikap terhadap perilaku yang merupakan faktor internal yang mempengaruhi perilaku pengusaha UMKM. Selain faktor internal terdapat faktor eksternal yaitu norma subyektif yang mempengaruhi perilaku pengusaha UMKM di dalam pembuatan keputusan. Terdapat kemungkinan perbedaan perilaku pengusaha UMKM dengan adanya pengaruh faktor eksternal tersebut.

(2) Penelitian ini tidak memperhatikan perbedaan industri termasuk skala usaha UMKM yang diteliti. Perbedaan jenis dan skala usaha akan mempengaruhi pemanfaatan informasi akuntansi dalam pembuatan keputusan yang dilakukan oleh pelaku usaha tersebut. Kemungkinan pemahaman akuntansi dan jiwa kewirausahaan dari masing-masing skala usaha tersebut berbeda sehingga akan mempengaruhi pembuatan keputusan investasi.

\section{KESIMPULAN}

Penelitian ini mengungkapkan persepsi pengusaha UMKM atas penggunaan informasi akuntansi yang mendukung jiwa kewirausaan dalam pembuatan keputusan investasi. Pengetahuan akuntansi memperkuat peran jiwa kewirausahaan dalam pembuatan keputusan investasi. Hal ini menunjukkan bahwa pengetahuan akuntansi sangat diperlukan oleh pelaku usaha UMKM. Semakin tinggi pengetahuan akuntansi pengusaha UMKM maka semakin tinggi pula peran jiwa kewirausahaan untuk mempengaruhi pembuatan keputusan investasinya. Saran yang dapat diberikan untuk pengembangan dari hasil penelitian ini adalah sebagai berikut:

(1) Para pengusaha UMKM disarankan untuk meningkatkan dan memperdalam pengetahuan akuntansi karena sangat diperlukan dalam membaca dan memahami informasi akuntansi dalam rangka membuat keputusan investasi. Paling tidak, informasi cash flow perusahaan dapat dimanfaatkan untuk memprediksi kas masa depan perusahaan. Apabila wirausahawan menggunakan informasi akuntansi dalam pengambilan keputusan investasinya yang disertai dengan pemahaman yang baik terhadap pengetahuan akuntansi, maka akan menghasilkan keputusan yang tepat bagi masa depan usahanya.

(2) Untuk penelitian selanjutnya dapat menambahkan peran norma subyektif dari konstruk TPB (Theory of Planned Behavior). Hal ini dapat memberikan gambaran bahwa selain faktor internal terdapat faktor ekternal yang mempengaruhi perilaku wirausahawan.

(3) Untuk penelitian selanjutnya agar memperhaikan perbedaan jenis industri dan skala usaha yang dapat mempengaruhi peran informasi akuntansi dalam pembuatan keputusan yang dilakukan oleh pelaku usaha tersebut sehingga lebih menjelaskan validitas internal dari hasil penelitian. 


\section{DAFTAR PUSTAKA}

Aprianto, Agus. (2014). Pengaruh Pengetahuan Akuntansi dan JiwaKewirausahaan Terhadap Penggunaan Informasi Akuntansi Dalam Pengambilan Keputusan Investasi. Skrips Universitas Mahasaraswati, Denpasar

Hadiyah Fitriyah. (2006). Analisis Faktor - Faktor yang Mempengaruhi Penggunaan Informasi 64 Matrik : Jurnal Manajemen, Strategi Bisnis dan Kewirausahaan Vol. 13, No. 1, Februari 2019 Akuntansi Pada Usaha Kecil dan Menengah. Tesis Universitas Negeri Jakarta Hafij Ullah,

Jogiyanto.HM. (2007). Sistem Informasi Keperilakuan. Abdi. Yogyakarta (2011).

Teori Portofolio dan Analisis Investasi. Edisi 7. Yogyakarta: BPFE Universitas Gadjah Mada

Indarti Nurul dan Rokhima Rostiani. (2008). Intensi Kewirausahaan Mahasiswa: Studi perbandingan antara Indonesia, Jepang dan Norwegia. Jurnal Ekonomika dan Bisnis Indonesia, 23(4) Kasmir. 2010.Kewirausahaan. Edisi 5. Rajagrafindo Persada. Jakarta

Kreitner, Robert and Angelo Kinicki. (2001). Organizational Behavior. Fifth Edition. Irwin McGraw-Hill. Krisanti, Rina. (2012). Pengaruh Pengetahuan Akuntansi dan Jiwa kewirausahaan Terhasap Penggunaan Informasi Akuntansi Dalam Pengambilan Keputusan Investasi. Jurnal Akuntansi dan Keuangan, 2(2), 127-137

Linawati Evi dan Mitha Dwi Restuti. (2015). Pengetahuan Akuntansi Pelaku Usaha Mikro, Kecil Dan Menengah (UMKM) Atas Penggunaan Informasi Akuntansi. Conference in Business, Accounting and Management, 2(1), ISSN 2302-9791

Roudah, Ria. (2008). Pengaruh Pengetahuan Akuntansi dan Kepribadian Wirausaha Terhadap Penggunaan Informasi Akuntansi dalam Keputusan Investasi (Studi Kasus UKM Sektor Dagang di Kota Surabaya). Skripsi, STIE PERBANAS

Sari, Ni Made Ari Maya. (2015). Pengaruh Kepribadian Wirausaha dan Pengetahuan Akuntansi Pada Penggunaan Informasi Akuntansi dalam Pembuatan Keputusan Investasi. E-Jurnal Akuntansi Universitas Udayana, 11(1), 303-319

Siregar, Aditya Fitri. (2009). Pengaruh Pengetahuan Akuntansi dan Kepribadian Wirausaha Terhadap Kinerja Manajerial Pada Perusahaan Jasa Di kota Medan. Skripsi, Universitas Sumatra Utara, Medan

Suhairi, Sofri Yahya, dan Hasnah Haron. (2004). Pengaruh Pengetahuan Akuntansi dan Kepribadian Wirausaha Terhadap Penggunaan Informasi Akuntansi Dalam Pengambilan Keputusan Investasi. Simposium Nasional Akuntansi VIII, 1-19, Denpasar.

Syairozi, M. I. (2011). Analisis peranan sektor pertanian terhadap produk domestik regional bruto (PDRB) di kabupaten Malang (periode 2000-2008) (Doctoral dissertation, Universitas Negeri Malang).

Syairozi, M. I., Pambudy, A. P., \& Yaskun, M. (2021). Analisis Penerapan Good Governance dalam Sistem Informasi Keuangan Daerah. Prosiding Penelitian Pendidikan dan Pengabdian 2021, 1(1), 49-59.

Wahyudi, Muhamad. (2009). Analisis Faktor-faktor yang Mempengaruhi Penggunaan Informasi Akuntansi Pada UsahaKecil dan Menengah (UKM) di Yogyakarta. Tesis, Universitas Diponegoro, Semarang

Zimmerer, Thomas W, dan Norman M. Scarborugh. (2004). Pengantar Kewirausahaan dan Manajemen Bisnis Kecil. Edisi Bahasa Indonesia. PT Indeks. Jakarta 